Research Article

Animal Genetics

\title{
Molecular identification of Mazama species (Cervidae: Artiodactyla) from natural history collections
}

\author{
Aline Meira Bonfim Mantellatto ${ }^{1,2}$ iD, Susana González ${ }^{3}$ and José Maurício Barbanti Duarte ${ }^{1}$ \\ ${ }^{1}$ Universidade Estadual Paulista "Júlio de Mesquota Filho" (UNESP), Faculdade de Ciências Agrárias e \\ Veterinárias, Núcleo de Pesquisa e Conservação de Cervídeos, Jaboticabal, SP, Brazil. \\ ${ }^{2}$ Universidade Federal do Sul da Bahia, Centro de Formação em Ciências Ambientais, Laboratório de \\ Ecologia e Conservação Marinha, Campus Sosígenes Costa, Porto Seguro, BA, Brazil. \\ ${ }^{3}$ Instituto de Investigaciones Biológicas Clemente Estable, Departamento de Biodiversidad y Genética, \\ Montevideo, Uruguay.
}

\begin{abstract}
Natural history museum collections constitute an invaluable patrimony of biological diversity for analysing the taxa distribution and evolution. However, it is very common to discover taxonomic misidentification in museum collections based on incorrect data. The aim of this research was to identify brocket deer species (Mazama genus) using molecular markers. We collected 199 samples, performed DNA extraction and species identification using a specific mitochondrial marker based on a fragment of cytochrome b (Cytb) for Neotropical deer. We achieved the amplification and sequencing of 77 specimens and verified that $26 \%$ of the skulls were wrongly identified. Moreover, in the museum collections 57\% of the specimens were only identified as Mazama sp, and we were able to identify them by molecular methods to the species level. Our findings clearly demonstrate the importance of integrating molecular analyses to identify Mazama species, since using only external morphology can result in a high probability of errors. We recommend the selection of non-convergent morphological characters, which together with the use of DNA collected from museum specimens should contribute to more accurate taxonomic identifications.
\end{abstract}

Keywords: Cytochrome b, deer, DNA, mammal, morphological taxonomy.

Received: January 25, 2019; Accepted: August 02, 2019.

\section{Introduction}

Biological museum collections house millions of specimens worldwide (Wandeler et al., 2007), representing the diversity of plants and animals that exist in the world, and are the main source for consultation and the development of studies involving geographical and temporal distribution of living beings (Wandeler et al., 2007; Goodwin et al., 2015). The information contained on the labels of each specimen is always assumed to be correct, even though errors in taxonomic identification of specimens are commonly known to occur (Goodwin et al., 2015). The correct delimitation of boundaries between species is crucial to our knowledge of the diversity of life, as they determine whether or not the organisms in question are members of the same entity (Dayrat, 2005). In addition, the misidentification might detrimentally impact species conservation (George and

Send correspondence to Aline Meira Bonfim Mantellatto. Universidade Estadual Paulista "Júlio de Mesquota Filho" (UNESP), Faculdade de Ciências Agrárias e Veterinárias, Núcleo de Pesquisa e Conservação de Cervídeos, Jaboticabal, Rodovia BR - 367 Km 10, 45810-000, Porto Seguro, BA, Brazil. E-mail: alinemeira22@ hotmail.com.
Mayden, 2005; Gutiérrez and Helgen, 2013; Gippoliti et al., 2017).

Few studies have been designed to verify the extent of specimen misidentifications in museum collections. For example, Goodwin et al. (2015), evaluated the accuracy of names associated with plant species from 40 herbariums in 21 countries, and their results showed that at least $58 \%$ of the specimens were misidentified. One of the possible reasons of high identification errors is the decrease in the formation of new taxonomists, while the number of specimens in collections increases over time (Goodwin et al., 2015). Indeed, the profusion of identification errors associated with the names present in museum classifications give rise to taxonomic problems that affect hypotheses and ideas, and represents a deep practical problem that affects our knowledge about nature (Bortolus, 2008).

The genus Mazama Rafinesque 1817 (brocket deer) is a taxon that encompasses several species with convergent morphology that are very difficult to distinguish (Allen, 1915). The genus is considered one of the most remarkable and surprising cases of morphological convergence among mammals (Gilbert et al., 2006; Duarte et al., 2008, Gonzá- 
lez et al., 2010), with doubts remaining regarding the evolutionary relationships between the species described up to now. Previous morphological analyses performed by Merino et al. (2005) considered that Mazama is monophyletic. However several studies using several molecular analyses, such as isoenzymes (Smith et al., 1986), mitochondrial and nuclear markers (Gilbert et al., 2006, Duarte et al., 2008; Hassanin et al., 2012; Escobedo-Morales et al., 2016; Heckeberg et al., 2016; Gutiérrez et al., 2017) revealed the genus is polyphyletic.

Recent studies on species of Neotropical deer have further explored a combination of data on skull morphometrics and sequences of the cytochrome b $(C y t b)$ gene (Gutiérrez et al., 2015, 2017). However, taxonomic misidentification of species of the genus Mazama based on incorrect data might still be present in natural history collections, propagating misidentifications of species names.

Duarte et al. (2008) described one of the most amazing cases of morphological convergent evolution and cryptic species system in mammals, where brocket deer with very similar external morphologies showed high levels of molecular and cytogenetic differentiation. At least eight ancestral forms of deer invaded South America since the late Pliocene (2.5-3 MYA), and members of the red brockets had an independent early explosive diversification soon after their ancestor arrived there, giving rise to a number of morphologically cryptic species (Duarte et al., 2008). Taxonomic revision of this group based on cytogenetic data have proven to be more useful in comparison with morphological approaches in recognizing new cryptic species of red brockets from Mexico (Mazama temama; Groves and Grubb, 1987), and from Brazil (Mazama bororo; Duarte and Jorge, 2003).

Morphological and morphometric analyses have been performed on museum collections in Brazil, indicating high intraspecific polymorphism, hindering the process of discrimination between brocket deer species (Rossi RV, personal communication). This happens due to high levels of homoplasy in the morphological characters of Mazama
(Duarte et al., 2008; González et al., 2010). Thus, given the enormous potential of generating large amounts of DNA sequence data from museum specimens, sequencing tech-nologies offer one of the most promising approaches to resolve discrepancies in taxonomy (Gutiérrez et al., 2017).

Here, we used molecular markers to elucidate species-level brocket deer identifications in specimens from Brazilian natural history collections, as the genus Mazama contains several cryptic species and many doubts remain concerning the evolutionary relationships among the currently recognized species.

\section{Material and Methods}

\section{Mazama samples}

We collected samples from 199 Mazama specimens between September and December 2013, which were deposited in 10 Brazilian natural history collections over the past 100 years (Table 1 ).

We collected approximately $180 \mathrm{mg}$ of turbinate bone fragments of skulls from specimens labeled as genus Mazama (Wiseley et al., 2004). We used long-handled tweezers to remove these pieces of bone, and cleaned these instruments with bleach every time before handling the next specimen. The bone fragments were stored in sterilized $50 \mathrm{~mL}$ plastic tubes and identified with the museum's acronym and the collection number of the respective skull.

\section{DNA extraction, amplification and sequencing}

DNA extraction was performed using the protocol proposed by González et al. (2015). In order to minimize the risks of contamination and to ensure the reliability of the results, negative controls were used in all DNA extractions and were quantified in a NanoDrop 2000 spectrophotometer (Thermo Fisher Scientific, Delaware, USA). In addition, at all stages, we used filter tips and disposable gloves.

Table 1 - The natural history collections visited, their respective acronyms, locations and number of turbinate bones collected.

\begin{tabular}{lcc}
\hline Museum & City/State of Museum Location & No. of specimens obtained \\
\hline Museu de Zoologia da Universidade de São Paulo (MZUSP) & São Paulo, São Paulo & 49 \\
Museu Nacional do Rio de Janeiro (MNRJ) & Rio de Janeiro, Rio de Janeiro & 23 \\
Museu de História Natural Capão da Imbuia (MHNCI) & Curitiba, Paraná & 75 \\
Museu de História Natural Professor Adão José Cardoso (ZUEC) & Campinas, São Paulo & 6 \\
Museu de Biologia Professor Mello Leitão (MBML) & Santa Teresa, Espírito Santo & 12 \\
$\begin{array}{l}\text { Fundação Zoobotânica do Rio Grande do Sul (FZB) } \\
\text { Museu Anchieta (MAMM) }\end{array}$ & Porto Alegre, Rio Grande do Sul \\
$\begin{array}{l}\text { Museu de Zoologia da Pontifícia Universidade Católica do Rio Grande do Sul } \\
\text { (PUC-RS) }\end{array}$ & Porto Alegre, Rio Grande do Sul Alegre, Rio Grande do Sul & 3 \\
$\begin{array}{l}\text { Museu de Zoologia da Universidade Federal da Paraíba (UFPB) } \\
\text { Museu de Zoologia da Universidade Federal de Pernambuco (UFPE) }\end{array}$ & João Pessoa, Paraíba & 4 \\
\hline
\end{tabular}


Polymerase chain reactions (PCR) were performed in a laminar flow cabinet, accompanied by negative controls that were also submitted to the amplification step to confirm the absence of contaminating DNA in the reactions. We used specific primers (González et al., 2009) to amplify a $224 \mathrm{bp}$ region of the mitochondrial cytochrome $b$ gene (IDMAZ224L and IDMAZ H): forward sequence, 5' CATCCGACACAATAACAGCA 3'; reverse sequence, 5' TCCTACGAATGCTGTGGCTA 3'. Amplifications were performed in a real-time thermal cycler (Rotor Gene Qiagen Inc, Texas, USA), testing aliquots of extracted DNA of $10 \mathrm{ng} / \mu \mathrm{L}, 30 \mathrm{ng} / \mu \mathrm{L}, 50 \mathrm{ng} / \mu \mathrm{L}$ and $100 \mathrm{ng} / \mu \mathrm{L}$ (Lozier and Cameron, 2009; Tex et al., 2010; Woide et al., 2010; Allentoft et al., 2011; Andersen et al., 2011; Paplinska et al., 2011). The best result was achieved using aliquots at $10 \mathrm{ng} / \mu \mathrm{L}$. We then used these aliquots to amplify the 199 samples. The final volume of the amplification reactions was $20 \mu \mathrm{L}$, consisting of: $1 \mu \mathrm{L}$ of the SensiFast $^{\mathrm{TM}}$ HRM kit, $0.8 \mu \mathrm{M}$ of each primer, $0.3 \mu \mathrm{L}$ of BSA, $10 \mathrm{ng} / \mu \mathrm{L}$ of DNA and $6.9 \mu \mathrm{L}$ of water. After initial denaturation at $95^{\circ} \mathrm{C}$ for $2 \mathrm{~min}$, a protocol with three different profiles was run: $95^{\circ} \mathrm{C}$ for $5 \mathrm{~s}, 55^{\circ} \mathrm{C}$ for $10 \mathrm{~s}(10 \mathrm{cy}-$ cles), $54{ }^{\circ} \mathrm{C}$ for $10 \mathrm{~s}$ ( 15 cycles $), 53{ }^{\circ} \mathrm{C}$ for $10 \mathrm{~s}$ ( 15 cycles $)$ and $72{ }^{\circ} \mathrm{C}$ for $20 \mathrm{~s}$, followed by a final holding step for 5 min, before a melting curve analysis was run.

After purifying the samples according to the protocol described by Dorado-Pérez (2008), both strands (forward and reverse) were sequenced using an automated sequencer (3730XL DNA Analyzer, Applied Biosystems, California, USA). In order to confirm the results obtained, the amplifications and DNA sequencing reactions for each sample were performed twice in different laboratories.

\section{Molecular data analysis}

We visually analysed the quality of the sequences using PHRED software, included in the package CODON CODE ALIGNER version 6.0.2. Sequences with less than 50 bases with PHRED 20 were excluded. Sequence alignment was performed using CLUSTALW (Thompson et al., 1994), included in BIOEDIT version 7.2.5 (Hall, 1999). To identify the species of each specimen, the sequences obtained were compared with the reference sequences of $C y t b$ of 985 bp downloaded from GenBank, using the BLAST tool (blast.ncbi.nlm.nih.gov). The sequences were analysed in CIPRES SCIENCE GATEWAY (Miller et al., 2010) using the JMODELTEST version 2 (Darriba et al., 2012) to determine which evolutionary model best fit the gene under analysis. The criterion used to select the best model was the Bayes Information Criteria (BIC), with the Hasegawa, Kishino and Yano (HKY) model $+\mathrm{G}$ selected as the best fit.

BEAST software version 1.8.1 (Drummond et al., 2012) was used for phylogenetic tree inference based on Bayesian analysis, using 35,000,000 generations. This procedure grouped sample sequences from museum specimens with sequences of Mazama species in such a way that iden- tification of the species of each specimen was the most robust. We rooted the tree using a sequence of Rangifer tarandus. A $25 \%$ burn-in was applied. The convergence among runs was verified using TRACER version 1.6, and only effective sample size (ESS) results higher than 200 were accepted. The resulting trees were condensed in the TREEANNOTATOR software, and visualization of the trees was achieved using FIGTREE, version 1.3.1 (Rambaut, 2010).

Sequences of specimens of Mazama americana (Erxleben, 1777), Mazama nana (Hensel, 1872), Mazama bororo (Duarte, 1996), Mazama gouazoubira (Fischer, 1814) and Rangifer tarandus (Linnaeus, 1758) used for the phylogenetic tree inference are available in GenBank or the NUPECCE sequence database (Table 2).

\section{Results}

Following the identification on the label of each skull selected, we collected samples from 39 specimens of $M$. americana, one of Mazama rufa (Illiger, 1815), synonymous with $M$. americana, 58 of $M$. gouazoubira, 11 of Mazama simplicicornis (Illiger, 1815), synonymous with M. gouazoubira, two of M. nana, six of Mazama rufina (Bourcier and Pucheran 1852), synonymous with M. nana, and 82 identified as Mazama sp, resulting in 199 specimens total. Our samples included both recent specimens (1-20 years old) and very old ones ( $>81$ years old). However, information on specimen age on the respective label was only

Table 2 - Sequences used for phylogenetic tree inference, detailing the sample origin as recorded from museum label collections with sequences from known identification and GenBank access number.

\begin{tabular}{|c|c|c|c|}
\hline Species & $\begin{array}{c}\text { Specimen identi- } \\
\text { fication }\end{array}$ & $\begin{array}{c}\text { GenBank } \\
\text { Access }\end{array}$ & $\begin{array}{l}\text { Collection } \\
\text { location }\end{array}$ \\
\hline \multirow{4}{*}{$\begin{array}{l}\text { Mazama } \\
\text { americana }\end{array}$} & $\mathrm{T} 40$ & DQ789224.2 & Pará \\
\hline & T43 & MG786262 & Pará \\
\hline & $\mathrm{T} 110$ & DQ789201.2 & Paraná \\
\hline & $\mathrm{T} 205$ & DQ789215.2 & Paraná \\
\hline \multirow[t]{4}{*}{ Mazama bororo } & $\mathrm{T} 71$ & DQ789231.2 & São Paulo \\
\hline & $\mathrm{T} 72$ & MG786263 & São Paulo \\
\hline & T338 & MG786261 & $\begin{array}{c}\text { Paraná (in cap- } \\
\text { tivity) }\end{array}$ \\
\hline & Msg54 & DQ789187.2 & $\longrightarrow$ \\
\hline \multirow[t]{3}{*}{ Mazama nana } & $\mathrm{T} 2$ & DQ789214.2 & Paraguay \\
\hline & T53 & DQ789227.2 & $\begin{array}{c}\text { Paraná (in cap- } \\
\text { tivity) }\end{array}$ \\
\hline & $\mathrm{T} 185$ & DQ789210.2 & Paraná \\
\hline $\begin{array}{l}\text { Mazama } \\
\text { gouazoubira }\end{array}$ & $\mathrm{T} 112$ & DQ789202.2 & São Paulo \\
\hline $\begin{array}{l}\text { Rangifer } \\
\text { tarandus }\end{array}$ & & KX067075.1 & - \\
\hline
\end{tabular}

- indicates an unknown geographic location 
referenced in 162 specimens (Figure 1). The amplification success rate was $49.3 \%$ (Figure 1). The mean DNA quantified in all samples was $443 \mathrm{ng} / \mu \mathrm{L}$. Amplification success and specimen identification was 39\%.

Based on specimen grouping in the phylogenetic analysis, we identified three skulls of $M$. americana, 41 of M. gouazoubira, 12 of M. nana and 21 of M. bororo with high statistical support (Figure 2, Table S1). Compared with the information indicated on labels, our molecular identification highlighted differences in identification (Table 3). We determined that skulls from M. gouazoubira and M. nana had the lowest error rate. In contrast, skulls of $M$. americana had the highest error rate (Table 3 ).

\section{Discussion}

Our results show that molecular techniques are useful tools for increasing the reliability of Mazama identification in natural history collections. Further, we highlight that identification errors could propagate unrealistic names of the species, probably because of poorly made taxonomic revisions, based on a small sample and ignoring geographic variation, obscuring the diversity in Mazama.

Given that we worked with fragments of turbinate bones, which naturally have low DNA quality compared with fresh samples (e.g. blood), we expected to find low rates of success in DNA extraction, amplification and sequencing. DNA extracted from historical material is expected to be highly degraded and highly diluted, similar to DNA from non-invasive sampling (Taberlet et al., 1999). Variation exists in the preservation of DNA in historical specimens due to specimen age and type of museum preparation (McDonough et al., 2018), and also due to degradation by microorganisms, as well as oxidative and hydrolytic lesions that can further negatively affect DNA quality (Hall et al., 1997; Pääbo et al., 2004; Rohland et al., 2004; Tang 2006). In addition, several post-mortem processes cause DNA damage, and these processes are more significant for ancient DNA (Rambaut et al., 2009). Nonetheless, we were able to use molecular techniques to improve Mazama spe-

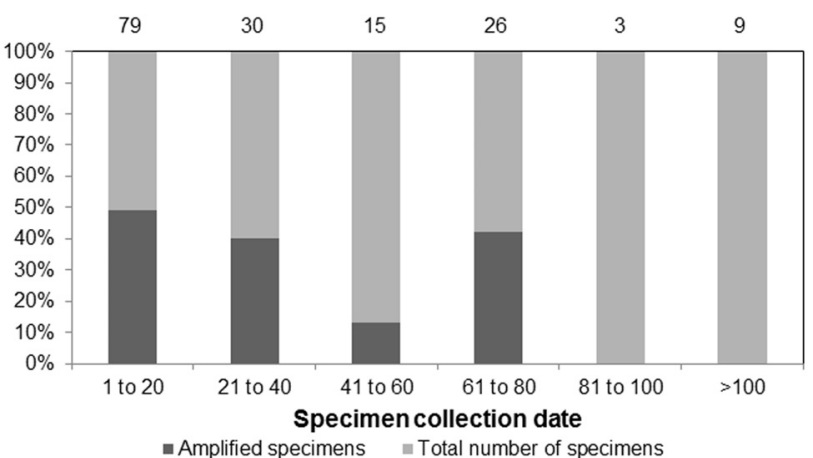

Figure 1 - DNA amplification success (dark grey) according to the collection date of 162 specimens from natural history collections. The numbers above the bars indicate the total number of specimens present in each time period and the numbers below the bars indicate the age of the samples. cies identification and highlight the importance of this tool for correct identification in natural history collections.

\section{Molecular analysis}

We obtained a very surprising result, showing that none of the skulls identified as $M$. americana were in fact $M$. americana. Indeed, $M$. americana is actually composed of several species, i.e. it is a complex of species (Duarte et al., 2008; Abril et al., 2010), which further complicates its morphologically identification. Another curious result was that 21 samples molecularly identified as $M$. bororo were not labelled as such in any of the museums. This can be explained by the recent description of this species (Duarte and Giannoni, 1996) and the fact that Mazama species are morphologically quite similar, further complicating taxonomic identification (Duarte, 1996). The absence of statistically

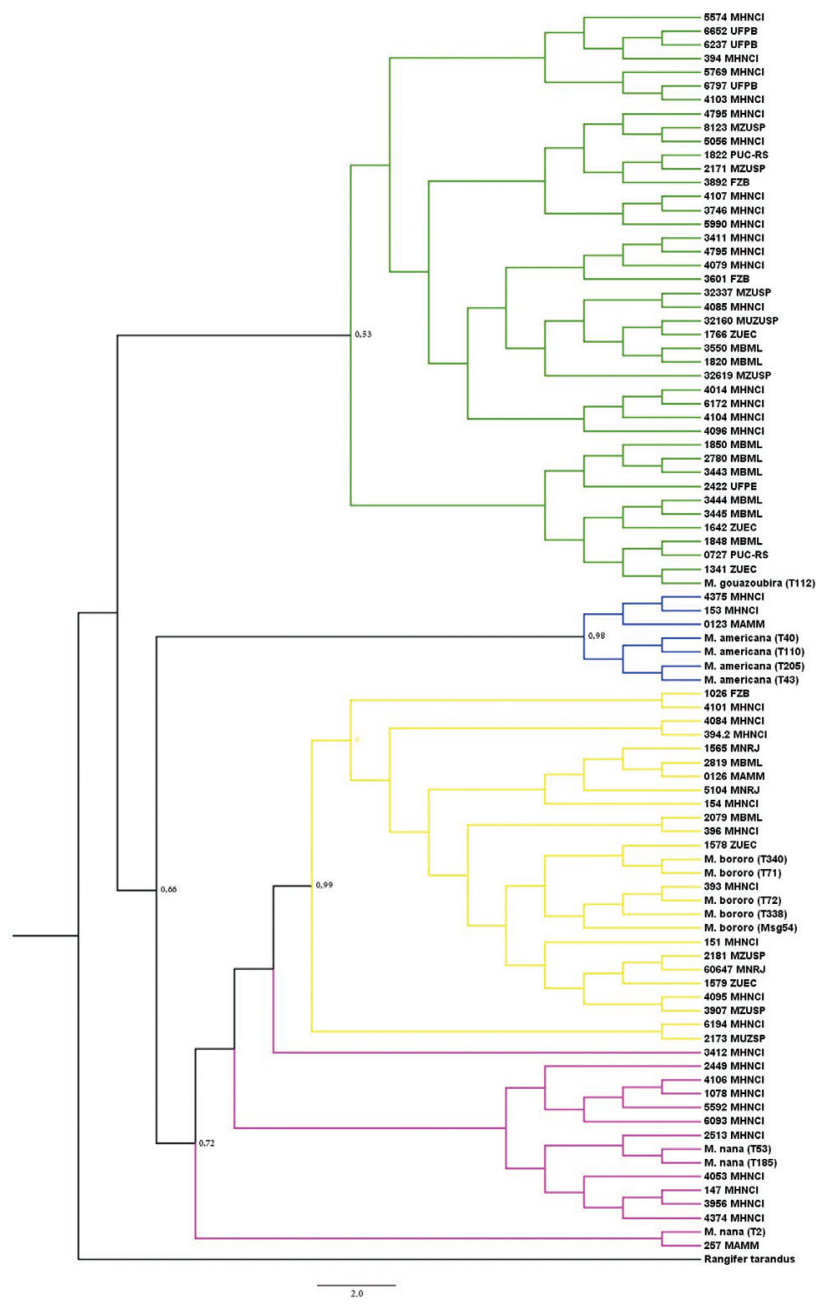

Figure 2 - Phylogenetic tree inferred from Bayesian analysis, demonstrating the relationships between recent DNA samples and museum collections within the genus Mazama, identified by a fragment of the mitochondrial Cytb. Reference samples are represented by the species name and identification code. Museum specimens are represented by their registration number and museum acronym. The colours indicate the four species identified in the museum specimens (M. americana, blue; M. nana, pink; M. bororo, yellow; M. gouazoubira, green). 
Table 3 - Comparison among the morphological information of 77 specimens identified with Cytb from Brazilian museum collections.

\begin{tabular}{llcccc}
\hline \multirow{2}{*}{ Museum identification } & & \multicolumn{2}{c}{ Molecular identification } \\
& & M. gouazoubira & M. americana & M. nana & M. bororo \\
\hline M. gouazoubira & 21 & 11 & 1 & 2 & 7 \\
M. americana & 7 & 3 & 0 & 1 & 3 \\
M. nana & 6 & 0 & 0 & 4 & 2 \\
Mazama sp. & 43 & 27 & 2 & 5 & 9 \\
Total & 77 & 41 & 3 & 12 & 21 \\
\hline
\end{tabular}

significant morphometric differences between the skulls of M. bororo and M. americana was observed by Rossi RV (personal communication). Our molecular analysis indicated that the rate of misidentification errors for every taxon based on morphological characters was $26 \%$. Very similar results were also reported by Moraes-Barros et al. (2011), who reviewed morphological and molecular data from museum collections of two species of sloths and observed identification errors attributed to the similarity in coat colouration.

Our results show the difficulty of correctly identifying brocket deer species based solely on cranial morphological characters. However, the taxonomy of Neotropical deer has been established almost entirely on the basis of descriptive morphological data, without the use of explicit phylogenetic methods (Gutiérrez et al., 2017). Similar to what we found, Duarte et al. (2008) demonstrated high levels of phylogenetic distinction between various forms of morphologically similar brocket deer, highlighting that phylogenetic relationships based on external morphological characters, such as pelage colouration and body size and shape, are problematic because of extensive homoplasy. In this case, the Cytb PCR protocol was extremely useful, since we were also able to identify $57 \%$ of our samples labelled as Mazama sp. (Table S1).

Our findings clearly demonstrate the importance of integrating molecular data to identify Mazama species, as using external morphology alone can result in a high rate of errors, given the several cryptic species in the genus $\mathrm{Ma}$ zama (Duarte et al., 2008). We also demonstrated the advantages of performing museum identifications using molecular markers, like Cytb. This method is economically advantageous, and only a very small amount of bone fragments is needed to obtain DNA from each specimen, minimally impacting the conservation of these collections. Further, it allows to update taxonomic identifications and better understand the evolutionary relationships of the taxa. We also recommend the selection of non-convergent morphological characters, which together with the use of museum DNA should contribute to more accurate taxonomic identifications.

\section{Acknowledgments}

We would like to thank João Boer (laboratory technician) for his assistance in the laboratory, and the São Paulo Research Foundation, FAPESP, for financial support (grant 2013/05944-7), and from Uruguay Agencia Nacional de Investigación e Innovación (ANII), and Lóreal-UnescoANII-MEC from Uruguay. We would also like to thank all the curators for authorising this work on the mastozoological collections of: Museum of Rio de Janeiro (MNRJ), Museum of Zoology of the University of São Paulo (MZUSP), National Museum of Rio de Janeiro (MNRJ), Professor Adão José Cardoso Museum of Natural History (ZUEC) Professor Mello Leitão Museum of Biology (MBML), Museum of Zoology of the Pontifical Catholic University of Rio Grande do Sul (PUC-RS), Zoobotanical Foundation of Rio Grande do Sul (FZB), Anchieta Museum, Museum of Zoology of the Federal University of Pernambuco (UFPE), Capão da Imbuia Museum of Natural History (MHNCI), Museum of Zoology of the Federal University of Paraíba (UFPB). We are also grateful to anonymous reviewers for their useful comments.

\section{Conflict of Interest}

The authors have no conflicts of interest to declare.

\section{Author Contributions}

$\mathrm{AMB}, \mathrm{SG}$, and JMB conceived and designed the study; AMB collected the samples, performed the molecular analysis and wrote the manuscript; SG and JMB made a critical review, adding improvements through comments and rewriting sentences; all authors read and approved the final version.

\section{References}

Abril VV, Carnelossi EAG, González S and Duarte JMB (2010) Elucidating the evolution of the Red Brocket Deer Mazama americana Complex (Artiodactyla; Cervidae). Cytogenet Genome Res 128:177-187.

Allen JA (1915) Notes on American deer of the genus Mazama. Bull Am Mus Nat Hist 34:521-553.

Allentoft ME, Oskam C, Houston J, Hale ML, Gilbert MTP, Rasmussen M, Spencer P, Jacomb C, Willerslev E, Holdaway $\mathrm{RN}$ et al. (2011) Profiling the dead: Generating 
microsatellite data from fossil bones of extinct Megafauna protocols, problems, and prospects. PLoS One 6:e16670.

Andersen K, Bird KL, Rasmussen M, Haile J, Breuning-Madsen H, Kjaer KH, Orlando L, Gilbert TP and Willerslev E (2011) Meta-barcoding of 'dirt' DNA from soil reflects vertebrate biodiversity. Mol Ecol 21:1966-1979.

Bortolus A (2008) Error cascades in the biological sciences: The unwanted consequences of using bad taxonomy in ecology. Ambio 37:114-118.

Darriba D, Taboada GL, Doallo R and Posada D (2012) jModelTest 2: More models, new heuristics and parallel computing. Nat Methods 9:772.

Dayrat B (2005) Towards integrative taxonomy. Biol J Linn Soc 85:407-415.

Dorado-Pérez G (2008) Purificación y análisis de DNA cromosómico bacteriano. In: Abril Díaz N, Dorado Pérez G, Galván Cejudo A, Jorrín Novo JV, Martínez Galisteo E, Padilla Peña CA, Peinado Peinado J, Tena Aldave M and Túnez Fiñana I (eds) Prácticas Generales de Bioquímica y Biología Molecular. Universidad de Córdoba, Córdoba, pp 1-12.

Drummond AJ, Suchard MA, Xie D and Rambaut A (2012) Bayesian phylogenetics with BEAUti and the BEAST 1.7. Mol Biol Evol 29:1969-1973.

Duarte JMB (1996) Guia de identificação de cervídeos brasileiros. FUNEP, Jaboticabal, 14 pp.

Duarte JMB and Giannoni MLA (1996) A new species of deer in Brazil (Mazama bororo). Deer Specialist Group Newsletter 13:5.

Duarte JMB and Jorge W (2003) Morphologic and cytogenetic description of the small red brocket (Mazama bororo Duarte, 1996) in Brazil. Mammalia 67:403-410,

Duarte JMB, González S and Maldonado JE (2008) The surprising evolutionary history of South American deer. Mol Phylogenet Evol 49:17-22.

Escobedo-Morales LA, Mandujano S, Eguiarte LE, RodríguezRodríguez MA and Maldonado JE (2016) First phylogenetic analysis of Mesoamerican brocket deer Mazama pandora and Mazama temama (Cetartiodactyla: Cervidae) based on mitochondrial sequences: Impli-cations on Neotropical deer evolution. Mamm Biol 81:303-313.

George AL and Mayden RL (2005) Species concepts and the endangered species act: How a valid biological definition of species enhances the legal protection of biodiversity. Nat Resour J 45:369-407.

Gilbert C, Ropiquet A and Hassanin A (2006) Mitochondrial and nuclear phylogenies of Cervidae (Mammalia, Ruminantia): Systematics, morphology, and biogeography. Mol Phylogenet Evol 40:101-117.

Gippoliti S, Cotterill FPD, Zinner D and Groves CP (2017) Impacts of taxonomic inertia for the conservation of African ungulate diversity: An overview. Biol Rev 93:115-130.

González S, Maldonado JE, Ortega J, Talarico AC, Bidegaray BL, Garcia JE and Duarte JMB (2009) Identification of the endangered small red brocket deer (Mazama bororo) using noninvasive genetic techniques (Mammalia; Cervidae). Mol Ecol Resour 9:754-758.

González S, Duarte JMB and Maldonado JE (2010) Molecular phylogenetics and evolution. In: Duarte JMB and González S (eds) Neotropical Cervidology, Biology and Medicine of Latin American Deer. FUNEP, Jaboticabal, pp 12-17.
González S, Mannise N, Repetto L and Maldonado JE (2015) Sex determination of three Neotropical canids by high resolution melting analysis. Conserv Genet Resour 7:643-645.

Goodwin ZA, Harris DJ, Filer D, Wood JRI and Scotland RW (2015) Widespread mistaken identity in tropical plant collections. Curr Biol 25:R1066-7.

Gutiérrez EE and Helgen KM (2013) Outdated taxonomy blocks conservation. Nature 495:314.

Gutiérrez EF, Maldonado JE, Radosavljevic A, Molinari J, Patterson BD, Martínez-C JM, Rutter AR, Hawkins MTR, Garcia FJ and Helgen KM (2015) The taxonomic status of Mazama bricenii and the significance of the Táchira depression for mammalian endemism in the Cordillera de Mérida, Venezuela. Plos One 10:e0129113.

Gutiérrez EF, Helgens KM, McDonough MM, Bauer F, Hawkins MTR, Escobedo-Morales LA, Patterson BD and Maldonado JE (2017) A gene-tree test of the traditional taxonomy of American deer: The importance of voucher specimens, geographic data, and dense sampling. ZooKeys 697:87-131.

Hall LM, Willcox MS and Jones DS (1997) Association of enzyme inhibition with methods of museum skin preparation. Biotechniques 22:928-934.

Hall TA (1999) BioEdit: A user-friendly biological sequence alignment editor and analysis program for Windows 95/98/NT. Nucleic Acids Symp Ser 41:95-98.

Hassanin A, Delsuc F, Ropiquet A, Hammer C, van Vuuren BJ, Matthee C, Ruiz-Garcia M, Catzeflis F, Areskoug V, Nguyen TT et al. (2012) Pattern and timing of diversification of Cetartiodactyla (Mammalia, Laurasiatheria), as revealed by a comprehensive analysis of mitochondrial genomes. $C R$ Biol 335:32-50.

Heckeberg NS, Erpenbeck D, Wörheide G and Rössner GE (2016) Systematic relationships of five newly sequenced cervid species. PeerJ 4:e2307.

Lozier JD and Cameron SA (2009) Comparative genetic analyses of historical and contemporary collections highlight contrasting demographic histories for the bumble bees Bombus pensylvanicus and $B$. impatiens in Illinois. Mol Ecol 18:1875-1886.

McDonough MM, Parker LD, McInerney NR, Campana MG and Maldonado JE (2018) Performance of commonly requested destructive museum samples for mammalian genomic studies. J Mammal 99:789-802.

Merino ML, Milne N and Vizcaíno SF (2005) A cranial morphometric study of deer (Mammalia, Cervidae) from Argentina using three-dimensional landmarks. Acta Theriol 50:91-108.

Miller MA, Pfeiffer W and Schwartz T (2010) Creating the CIPRES Science Gateway for inference of large phylogenetic trees. In: Proceedings of the Gateway Computing Environments Workshop (GCE). New Orleans, pp 1-8.

Moraes-Barros N, Silva JAB and Morgante JS (2011) Morphology, molecular phylogeny, and taxonomic inconsistencies in the study of Bradypus sloths (Pilosa: Bradypodidae). J Mammal 92:86-100.

Pääbo S, Poinar H, Serre D, Jaenicke-Després V, Hebler J, Rohland N, Kuch M, Krause J, Vigilant L and Hofreiter M (2004) Genetic analyses from ancient DNA. Annu Rev Genet 38:645-679.

Paplinska JZ, Taggart DA, Corrigan T, Eldridge MDB and Austin JJ (2011) Using DNA from museum specimens to preserve 
the integrity of evolutionarily significant unit boundaries in threatened species. Biol Conserv 144:290-297.

Rambaut A, Ho SYW, Drummond AJ and Shapiro B (2009) Accommodating the effect of ancient DNA damage on inferences of demographic histories. Mol Biol Evol 26:245-248.

Rohland N, Siedel H and Hofreiter M (2004) Nondestructive DNA extraction method for mitochondrial DNA analyses of museum specimens. Biotechniques 36:814-821.

Smith MH, Branan WV, Marchinton L, Johns PE and Wooten MC (1986) Genetic and morphologic comparisons of red brocket and white tailed deer. J Mammal 67:103-111.

Taberlet P, Waits LP and Luikart G (1999) Noninvasive genetic sampling: look before you leap. Trends Ecol Evol 14:323-327.

Tang EPY (2006) Path to effective recovering of DNA from formalin- fixed biological samples in Natural History Collections, Workshop Summary. The National Academies Press, Washington, pp 52.

Tex R, Maldonado JE, Thorington R AND Leonard JA (2010) Nuclear copies of mitochondrial genes: Another problem for ancient DNA. Genetica 138:979-984.

Thompson JD, Higgins DG and Gibson TJ (1994) CLUSTAL W: Improving the sensitivity of progressive multiple sequence alignment through sequence weighting, position-specific gap penalties and weight matrix choice. Nucleic Acids Res 22:4673-4680.
Wandeler P, Hoeck PEA and Keller LF (2007) Back to the future: Museum specimens in population genetics. Trends Ecol Evol 22:634-642.

Wiseley SM, Maldonado JE and Fleische SCA (2004) Technique for sampling ancient DNA that minimizes damage to museum specimens. Conserv Genet 5:105-107.

Woide D, Zink A and Thalhammer S (2010) Technical Note: PCR analysis of minimum target amount of ancient DNA. Am J Phys Anthropol 142:321-327.

\section{Internet Resources}

Rambaut A (2010) FigTree version 1.3.1, http://tree.bio.ed.ac.uk/software/figtree/.

\section{Supplementary Material}

The following online material is available for this article: Table S1 - Molecular identification of DNA samples collections in museums based on $224 \mathrm{bp}$ fragment of the mitochondrial Cytb.

Associate Editor: Fabrício Rodrigues dos Santos

License information: This is an open-access article distributed under the terms of the Creative Commons Attribution License (type CC-BY), which permits unrestricted use, distribution and reproduction in any medium, provided the original article is properly cited. 